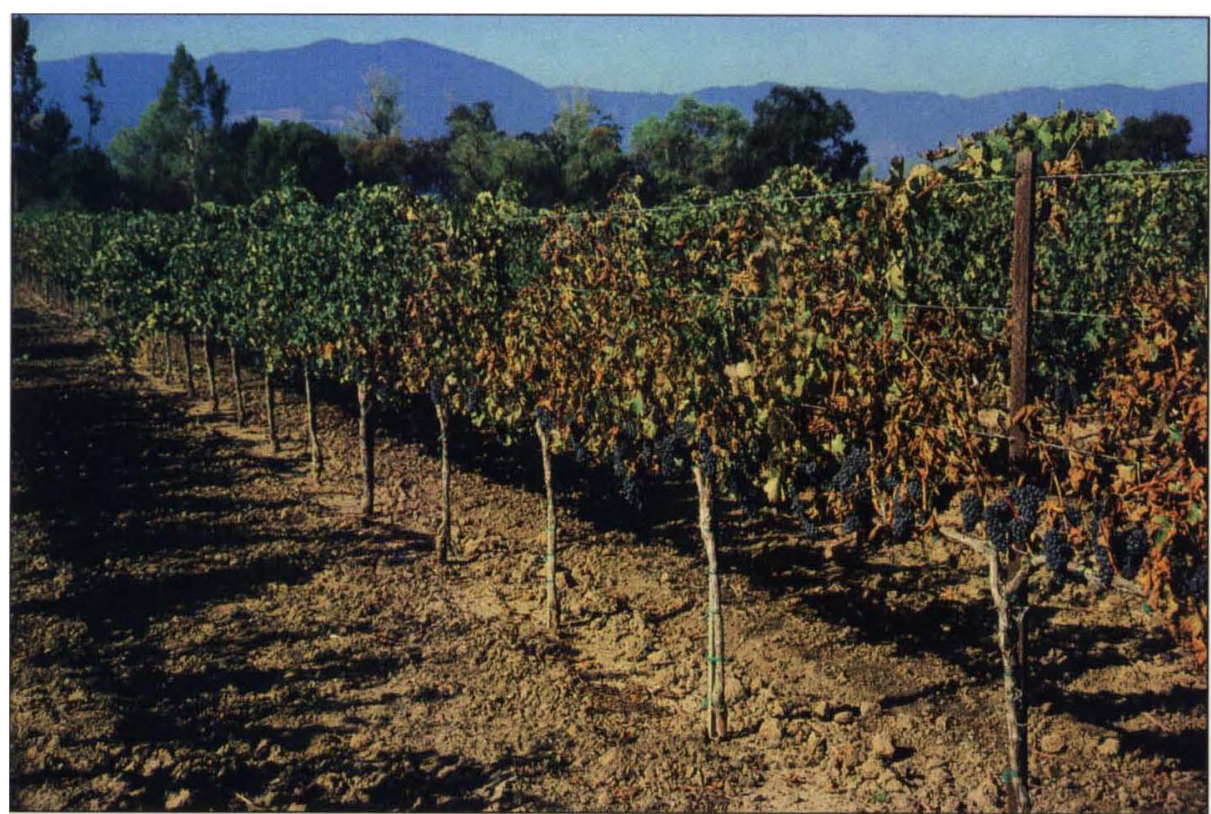

\section{Enzone does little to improve health of phylloxera-infested vineyards}

\author{
Ed Weber \\ John De Benedictis \\ ] Rhonda Smith \\ Jeffrey Granett
}

\begin{abstract}
Enzone was applied to phylloxerainfested vineyards in four trials in Napa and Sonoma counties from 1989 through 1994. Improvements in growth or yield were occasionally seen, but most occurred only after the vines had been severely affected by phylloxera and yields had plummeted.
\end{abstract}

Grape phylloxera, Daktulosphaira vitifolia (Fitch), are aphidlike insects that damage grapevines by feeding on roots. They can be destructive to vines that are own-rooted or grafted onto susceptible rootstocks. Rootstocks resistant to phylloxera have been used for over 100 years to combat this pest. In California's North Coast winegrape growing region (Napa, Sonoma, Lake and Mendocino counties), AxR\#1 has been the most popular rootstock. Recently a new strain of phylloxera,
Pockets of grapevines weakened from phylloxera feeding.

is difficult for a number of reasons. Phylloxera are often widely distributed throughout the root profile and can be found to great depths. Soil chemistry, especially $\mathrm{pH}$, may neutralize an insecticide and reduce its efficacy. Chemical movement through vineyard soils is uneven, depth of penetration is often insufficient and coverage is limited by some methods of application. In addition, there are often environmental concerns about groundwater contamination. Even when there is initial high mortality of phylloxera, populations can rebound due their high reproductive rate, and there may be little improvement in grapevine growth.

In California, only carbofuran (Furadan) and sodium tetrathiocarbonate (Enzone) are currently registered for use against phylloxera in vineyards. The use of carbofuran in Napa, Sonoma and Mendocino counties was banned in 1992 due to avian mortality associated with its use. Enzone was granted full California registration in 1994.

Enzone is a liquid formulation of sodium tetrathiocarbonate. It is applied to soil with irrigation water, where it rapidly breaks down to liberate predictable amounts of carbon disulfide $\left(\mathrm{CS}_{2}\right)$, a general biocide. Carbon disulfide was widely used in European vineyards during the phylloxera epidemic of the late $1800 \mathrm{~s}$, where it was injected into soils. This technique was dangerous because of the volatility and explosiveness of $\mathrm{CS}_{2}$, and it was often phytotoxic to the vines. The use of Enzone circumvents the danger of explosive volatility posed by direct application of $\mathrm{CS}_{2}$.

Studies in our laboratory confirmed that the concentrations of $\mathrm{CS}_{2}$ in vapors or solution expected from Enzone applications are lethal to adult phylloxera, larvae and eggs. From 1989 through 1994 we conducted several field studies to evaluate the efficacy of Enzone in phylloxera-infested North Coast vineyards. 


\section{Field trials}

Our primary interest in the field studies was to determine if grapevine growth and yield would improve as a result of Enzone applications. We monitored phylloxera populations in each trial, but we already knew from laboratory work that $\mathrm{CS}_{2}$ produced from Enzone could kill phylloxera. Simply reducing phylloxera populations would not be considered a successful outcome unless there were also positive effects on grapevine growth and production.

All experiments used randomized complete block designs in vineyards on AxR\#1 rootstock infested with biotype B phylloxera. Enzone was applied with drip irrigation in three trials and with furrow irrigation in one trial. Use of a spray-blade injector is discussed later in this article. Untreated controls were irrigated at the same rates as treated vines in all trials. Table 1 describes the vineyards used for the field trials.

At the onset of these trials there was no recommended strategy for using Enzone in vineyards. Treatments were selected with input from the manufacturer's research staff and were intended to evaluate efficacy and to develop an effective Enzone application strategy for North Coast vineyards. As a result, treatments varied among the field trials (table 2).

Napa 1992-1994. In 1991 the vineyard showed early signs of decline due to biotype B phylloxera. A trial with five replications of five treatments was initiated in 1992. Enzone was applied through the drip system at rates of 5 and 10 gallons per acre ( $\mathrm{gal} / \mathrm{ac}$ ). The other treatments were Enzone at these rates with the addition of potassium nitrate applied through the drip system, and a water-only control. Fertilizer additions made in 1992 and 1993 totaled approximately 5 pounds per acre $(\mathrm{lb} / \mathrm{ac}) \mathrm{N}$ and $15 \mathrm{lb} / \mathrm{ac} \mathrm{K}_{2} \mathrm{O}$ per season. Treatments were made to entire rows of grapevines. There were two 0.5-gallon-perhour (gph) emitters per vine.

In each of the three years, treatments were made in June, July and August, with additional applications

\begin{tabular}{|c|c|c|c|c|c|c|}
\hline Trial name & Location & Variety & $\begin{array}{l}\text { Irrigation } \\
\text { method }\end{array}$ & $\begin{array}{c}\text { Date } \\
\text { planted }\end{array}$ & $\begin{array}{l}\text { Row } x \text { vine } \\
\text { spacing }(\mathrm{ft})\end{array}$ & $\begin{array}{l}\text { Pruning } \\
\text { method }\end{array}$ \\
\hline Napa 1992-1994 & Carneros & Chardonnay & Drip & 1975 & $6 \times 10$ & $\begin{array}{l}\text { Canes \& } \\
\text { spurs }\end{array}$ \\
\hline Sonoma 1991-1994 & Sonoma Valley & Chardonnay & Drip & 1974 & $6 \times 12$ & $\begin{array}{l}\text { Canes \& } \\
\text { spurs }\end{array}$ \\
\hline Napa 1990-1991 & St. Helena & Chardonnay & Drip & 1978 & $8 \times 12$ & Cordon \\
\hline Napa 1989-1990 & Rutherford & $\begin{array}{l}\text { Cabernet } \\
\text { Sauvignon }\end{array}$ & Furrow & 1974 & $8 \times 12$ & $\begin{array}{l}\text { Canes \& } \\
\text { spurs }\end{array}$ \\
\hline Trial name & & $\begin{array}{l}\text { Number of } \\
\text { treatments }\end{array}$ & \multicolumn{4}{|c|}{ Treatment descriptions } \\
\hline Napa 1992-1994 & & 5 & \multicolumn{4}{|c|}{$\begin{array}{l}\text { Water-only control } \\
5 \text { gal/acre Enzone } \\
5 \text { gal/acre Enzone + fertilizer } \\
10 \text { gal/acre Enzone } \\
10 \text { gal/acre Enzone + fertilizer }\end{array}$} \\
\hline Sonoma 1991-1994 & & 2 & \multicolumn{4}{|c|}{$\begin{array}{l}\text { Water-only control } \\
7 \text { gal/acre Enzone (15 gal/acre in 1991) }\end{array}$} \\
\hline Napa 1990-1991 & & 2 & \multicolumn{4}{|c|}{$\begin{array}{l}\text { Water-only control } \\
15 \text { gal/acre Enzone }\end{array}$} \\
\hline Napa 1989-1990 & & 2 & \multicolumn{4}{|c|}{$\begin{array}{l}\text { Water-only control } \\
\text { Enzone @ } 300 \mathrm{ppm} \text { ai }\end{array}$} \\
\hline
\end{tabular}

in May 1993 and following harvest in October 1992 and 1993. In each singlerow replicate, 21 vines were selected for data collection. Nine were used for root sampling and phylloxera rating; 12 were used to evaluate crop yields and vine growth. The same data vines were evaluated each year.

Phylloxera populations were rated by digging roots from soil underneath the drip emitters and examining them for the presence of phylloxera. Vines received a rating based on the highest population found among the root pieces examined. Ratings were made on 3 vines per replicate on each sampling date. Vines were rated on the numbers of phylloxera found, as follows:

0 - No phylloxera found.

1 - Phylloxera only on rootlets, or one or two individuals on older (than 1 year) roots.

2 - Individual phylloxera scattered among older roots, or one or two colonies on older roots.

3 - Several colonies established on older roots.

4 - Large populations of phylloxera present on older roots.

Berry samples were collected from each replicate prior to harvest and weighed. Extracted juice was analyzed for sugar (degrees Brix), titratable acidity and $\mathrm{pH}$. At harvest, the 12 data vines in each replicate with undisturbed roots were individually harvested. Crop weight and cluster number per vine were measured and average cluster weights were calculated. Numbers of berries per cluster were calculated from average cluster weight and berry weight data. During the dormant season, pruning weights of 1-year-old wood were measured as an indicator of vine growth. Treatment means were subjected to analysis of variance.

Sonoma 1991-1994. The trial was conducted in 20 rows, each containing 80 vines. Enzone or a water-only control treatment, replicated 10 times, was applied to entire rows through the drip system. There were two 1-gph emitters per vine. Phylloxera were present throughout the trial area when it was established in 1991, although only half of the vines were symptomatic.

Treatments were applied four or five times per year. In 1991, $15 \mathrm{gal} / \mathrm{ac}$ of Enzone were applied on each application date for a total of $75 \mathrm{gal} / \mathrm{ac}$. In the following years, application rates were $7 \mathrm{gal} / \mathrm{ac}$ and the total amount of Enzone applied ranged from 28 to $35 \mathrm{gal} / \mathrm{ac}$. 


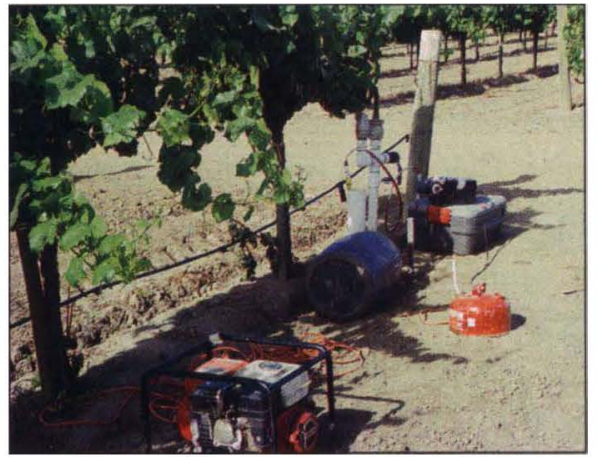

We selected five vines per row as data vines, from which yield components and pruning weights were individually measured throughout the duration of the trial. Opposite-cluster bloomtime petioles and preharvest berry samples were collected by replicate. Crop yields from entire individual rows (replicates) were also taken. Roots were collected from each replicate on two or three dates each year, and phylloxera populations were assessed by a private consultant.

Napa 1990-1991. The vineyard was planted in 1978 and irrigated with overhead sprinklers until 1990, at which time a drip irrigation system was installed specifically for the application of Enzone. There were two 1-gph emitters per vine. Twelve replications of two treatments were used for the trial: Enzone applied through the drip system at $15 \mathrm{gal} / \mathrm{ac}$ and a water-only control. Treatments were applied to entire rows of vines. Three applications were made in 1990 (May, August and October) and four in 1991 (June, July, August and November).

In each single-row replicate, 14 data vines were selected for data collection. Six were used for phylloxera ratings and 8 were used to evaluate crop yields and vine growth. The same data vines were used each year. Phylloxera ratings and growth and yield measurements were made as described above for the Napa 1992-1994 trial.

Napa 1989-1990. Our first field trial of Enzone used furrow irrigation and included eight replications comparing Enzone applications to control treatments of water only. A pretreatment survey of roots revealed phylloxera throughout most of trial area, even though most vines appeared healthy. Replicates consisted of two adjacent

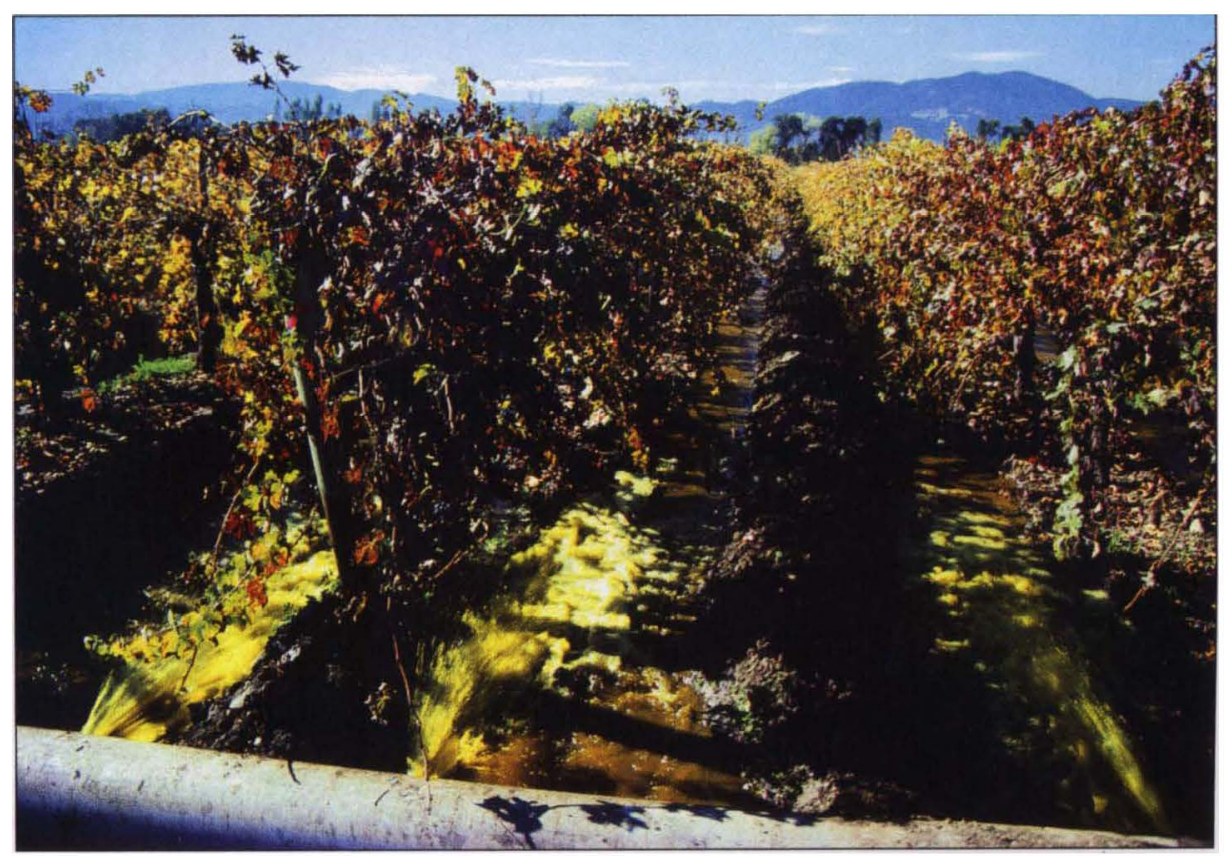

Above left, equipment for injecting Enzone into individual drip lines. Above, Enzone being applied with furrow irrigation.

rows 102 to 104 vines long. Berms of soil were raised between every vine row to contain the applied irrigation water. An untreated buffer zone two vine rows wide was used between Enzone and control treatments. Well water was delivered to the appropriate areas via 12 -inch surface irrigation pipes. Enzone was injected into the irrigation waters to reach a final concentration of $300 \mathrm{ppm}$ ai.

Treatments were made in November 1989 and May 1990 to coincide with fall and spring root flushes. No additional treatments were made because the vineyard was removed following harvest in 1990.

Phylloxera ratings, as previously described, were made at every tenth vine in one row of each replicate before and 3 to 4 weeks after each Enzone application, and again 1 week after harvest in 1990. A vigor rating based on the appearance of the vines was made in October 1989, prior to the first application, and again in September 1990, a week prior to harvest. All vines in one row per replicate were rated on a scale from 1 to 5 , with 5 representing vines with strong growth and healthy appearance and 1 representing vines that were severely stunted from phylloxera damage.

Prior to harvest in 1990, berry samples were collected from each rep- licate and analyzed for berry weight, degrees Brix, titratable acidity and $\mathrm{pH}$. At harvest, all the fruit from each tworow replicate was harvested by a commercial picking crew, placed in gondolas, and weighed.

\section{Field trial results}

Napa 1992-1994. There were no significant differences $(p>0.05)$ in fruit production in any year between the individual treatments, and few significant differences in phylloxera ratings or fruit composition (data not shown). However, when orthogonal contrasts were used to compare all Enzone treatments to the water-only control, some differences were found (tables 3 and 4).

Phylloxera populations were reduced by Enzone applications (table 3 ). That the reduction was not seen at each sampling date is probably a limitation of our sampling method in a drip-irrigated vineyard (some root pieces may have come from the margin or outside of the wetted area and thus not been fully exposed to lethal $\mathrm{CS}_{2}$ concentrations) and a function of the lower phylloxera populations in the second and third years of the trial.

It is interesting to note that the phylloxera ratings in the untreated control vines were much lower in 1993 and 1994 than in 1992 (table 3). This is 


\begin{tabular}{|c|c|c|c|c|c|c|c|c|c|c|c|c|}
\hline \multirow[b]{2}{*}{ Treatment } & \multicolumn{4}{|c|}{1992} & \multicolumn{4}{|c|}{1993} & \multicolumn{4}{|c|}{1994} \\
\hline & Jun* & Jul & Aug & Sep & May & Jun & Jul & Oct & May & Jun & Jul & Oct \\
\hline Control & 2.33† & 3.20 & 2.33 & 3.20 & 0.87 & 1.07 & 1.07 & 1.87 & 0.83 & 0.53 & 1.07 & 1.87 \\
\hline Enzone & $2.77^{\circ}$ & 1.85 & 1.52 & 2.23 & 0.47 & 0.63 & 1.13 & 1.10 & 0.73 & 0.47 & 0.57 & 1.85 \\
\hline prob. & 0.231 & 0.003 & 0.031 & 0.028 & 0.046 & 0.001 & 0.731 & 0.013 & 0.505 & 0.671 & 0.004 & 0.940 \\
\hline
\end{tabular}

*Prior to first Enzone applications.

tSee text for description of phylloxera rating scale $0-4$.

TABLE 4. Napa 1992-1994: Effect of drip applications of Enzone on crop weight, cluster number and pruning weights in a phylloxera-infested Chardonnay/AxR\#1 vineyard

\begin{tabular}{|c|c|c|c|c|}
\hline Year & Treatment & $\begin{array}{l}\text { Lb/vine* } \\
\text { (tons/acre) }\end{array}$ & Clusters/vine & Pruning weight \\
\hline & & & & $\mathrm{lb} /$ vine \\
\hline \multirow[t]{3}{*}{1992} & Control & $13.1(4.8)$ & 31.5 & 1.36 \\
\hline & Enzone & $13.3(4.8)$ & 33.1 & 1.43 \\
\hline & prob. & 0.829 & 0.444 & 0.629 \\
\hline \multirow[t]{3}{*}{1993} & Control & $5.01(1.8)$ & 12.1 & 0.78 \\
\hline & Enzone & $6.09(2.2)$ & 14.1 & 0.97 \\
\hline & prob. & 0.061 & 0.079 & 0.005 \\
\hline \multirow[t]{3}{*}{1994} & Control & $5.17(1.8)$ & 11.1 & 0.89 \\
\hline & Enzone & $6.97(2.5)$ & 13.7 & 1.14 \\
\hline & prob. & 0.059 & 0.035 & 0.006 \\
\hline
\end{tabular}

${ }^{*}$ Crop weights collected from 300 data vines. Tons/acre based on 726 vines/acre.

likely due to the weakened condition of the vines, as evidenced by their reduced growth and yield. When evaluating phylloxera, we have repeatedly seen that weakened vines do not support large phylloxera populations, whereas nearby vines that appear healthy can support large populations.

Enzone applications led to yields that were nearly significantly greater than control vines $(p=0.06)$ in the second and third years of the trial (table 4), due primarily to higher cluster counts. However, yield throughout the block, including the Enzone treatments, plummeted from an average of 4.8 tons per acre in 1992 to just over 2 tons per acre in 1993 and 1994 (fig. 1).

There was a similar reduction in vine growth after 1992, as indicated by pruning weights (table 4). Enzonetreated vines had higher pruning weights than control vines in 1993 and 1994, but both treated and untreated vines had considerably lower pruning weights than they had in 1992. There were no significant differences in cluster weights, berry weights, berries per cluster or juice analyses in any year (data not shown).
While Enzone applications led to small yield improvements in 1993 and 1994, production in these years was considerably lower than in 1991 and 1992 (fig. 2).

Nutrient levels in petioles collected in 1994 (data not shown) indicated that Enzone-treated vines had significantly higher levels of potassium and zinc, and lower levels of calcium and magnesium, than did control vines $(p<0.05)$, while petiole nitrate-nitrogen levels did not differ.

Enzone applications significantly reduced the number of phylloxera or eggs found on roots on at least one sample date each year (data not shown).

Napa 1990-1991. Reductions in phylloxera populations were observed on some sampling dates; however, there were no significant differences in any vine growth or yield parameters measured in either year of the study (data not shown). The trial was discontinued after the second year and the vineyard was subsequently replanted.

The vines were 12 years old when the trial began. Previously, the vineyard had been irrigated with overhead sprinklers and the vines had developed a deep, well-distributed root system. Because there was no history of drip irrigation, there was no concentration of roots below the emitters, as would typically occur. As a result, our Enzone applications were likely affecting a smaller percentage of the overall root system than would occur in vineyards that have been continuously drip irrigated.

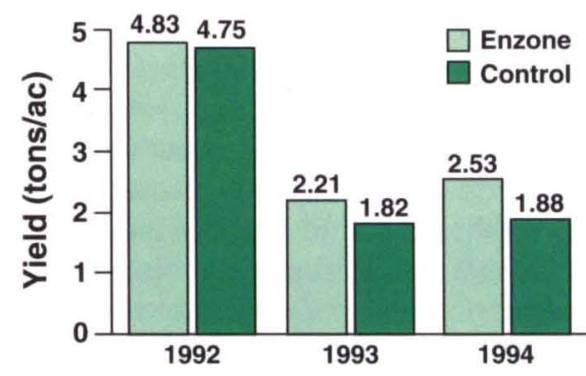

Fig. 1. Yield comparisons of Enzonetreated and control (water-only) vines, Napa 1992-1994 trial. Data collected from 300 selected data vines; tons/acre based on 726 vines/acre.

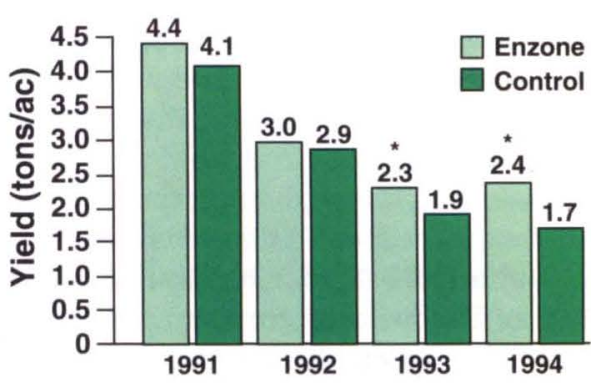

Fig. 2. Yield comparisons of Enzonetreated and control (water-only) vines, Sonoma 1991-1994 trial. Data collected from all treated and control vines; tons/ acre based on 605 vines/acre.

*Yields were significantly different $(p<0.05)$ in 1993 and 1994. 


\begin{tabular}{|c|c|c|c|c|}
\hline Year* & Treatment & $\begin{array}{c}\text { Lb/vine } \\
\text { (tons/acre) } \dagger\end{array}$ & Cluster weight & Berry weight \\
\hline & & & Ib & $g m$ \\
\hline 1993 & $\begin{array}{l}\text { Control } \\
\text { Enzone } \\
\text { Probability }\end{array}$ & $\begin{array}{l}6.4(1.9) \\
8.2(2.5) \\
0.001\end{array}$ & $\begin{array}{l}0.27 \\
0.30 \\
0.006\end{array}$ & $\begin{array}{l}0.81 \\
0.89 \\
0.001\end{array}$ \\
\hline 1994 & $\begin{array}{l}\text { Control } \\
\text { Enzone } \\
\text { Probability }\end{array}$ & $\begin{array}{l}6.2(1.9) \\
9.2(2.8) \\
0.001\end{array}$ & $\begin{array}{l}0.27 \\
0.33 \\
0.006\end{array}$ & $\begin{array}{l}1.05 \\
1.17 \\
0.018\end{array}$ \\
\hline
\end{tabular}

*Enzone applied 1991-1994.

†Crop weights collected from 100 data vines. Tons/acre based on 605 vines/acre.

Napa 1989-1990. The first application of Enzone in November 1989 reduced the phylloxera population from a rating of 3.0 to $0.6(p<0.001)$. The second Enzone application had little apparent effect; however, the population was already at a very low level prior to this application. By October 1990 the phylloxera populations had greatly increased, achieving a rating of 2.7 even within the Enzone treatments. Clearly, additional applications during the summer of 1990 would have been necessary to keep the population in check.

Despite the reestablishment of a large phylloxera population during the summer, vines treated with Enzone had significantly higher yields than the control vines (13.5 versus 12.2 $\mathrm{lb} /$ vine; $p=0.017$ ) due in part to greater berry weight (1.16 versus 1.09 $\mathrm{gm} ; p>0.009$ ).

Enzone-treated vines had higher vigor ratings in September 1990 than did the controls ( 3.7 versus 3.4 ; $p=0.041$ ). However, vigor ratings of both treated and control vines were lower than those made in October 1989 (4.5). This suggests that while all of the vines were damaged by phylloxera, Enzone applications slowed their rate of decline.

\section{Discussion}

Phylloxera populations typically increase in size for 1 to 3 years, during which time vine growth and production are relatively unaffected. An economic threshold for phylloxera populations is unknown; however, at a certain point growth and yield are markedly reduced and the vines be- come economically unproductive. Vines often remain in this weakened condition for several years before finally succumbing, during which time phylloxera populations are relatively low.

In our trials, Enzone applications through the drip system were unable to prevent the marked decline in vine productivity. In some trials, Enzonetreated vines did produce more than the controls, but their yield was still quite low. The increased production likely justified the cost of applying Enzone, but it is doubtful that the economic life of the vines was extended. Yields dropped to a point where many growers would have pulled out the vines whether they had been treated with Enzone or not.

Drip applications by their nature treat a limited volume of soil and reach only a fraction of the root system. In both the Napa 1992-1994 and Sonoma 1991-1994 trials, the vines were established with drip irrigation and likely had roots concentrated below the emitters. The Sonoma 19911994 trial showed a small positive yield response to Enzone, and the Napa 1992-1994 trial suggested one $(p<0.06)$. However, the yield improvements came only after 2 to 3 years, by which time productivity had been greatly reduced. There was no apparent response to Enzone in the Napa 1990-1991 trial, where the vineyard had no history of drip irrigation.

Application of Enzone with furrow irrigation greatly increases the percentage of the root system that can be treated. While we saw a good response with furrow irrigation with just two applications, it was clear that additional treatments would be required for adequate control of phylloxera. Unfortunately, nearly all vineyards in the North Coast region have uneven terrain or limited water availability, which prevents this type of irrigation. Additionally, applying large amounts of water during the summer would often be detrimental to fruit and wine quality.

Many of these vineyards, however, do have overhead sprinklers. In an attempt to treat a higher percentage of the root system than is possible with drip irrigation, we experimented with Enzone applications through a spray blade, followed by sprinkler irrigation to move the Enzone through the soil profile. However, this trial was discontinued after the first year as yields were reduced by $22 \%$ where the spray blade was used (data not shown). We attributed this crop loss to physical damage to the root system caused by the spray blade itself.

\section{Summary}

When applied to vineyard soils, Enzone kills phylloxera but may have little or no effect on vine growth and productivity. In order to keep phylloxera populations at a relatively low level, multiple applications are required. Furrow applications are likely to be more effective than drip applications, due to the increased coverage of the root system. To maximize the effectiveness of Enzone with drip irrigation, the vineyard should have a history of drip irrigation, and root coverage should be maximized by the number and size (gph) of emitters used per vine.

In our trials, Enzone-treated vines were still severely affected by phylloxera, and yields were greatly reduced. In some cases, Enzone applications led to higher yields after 2 or 3 years, but these yields were well below previous production levels.

E. Weber is Viticulture Farm Advisor, UC Cooperative Extension, Napa County; J. De Benedictis is Staff Research Associate and J. Granett is Professor, Department of Entomology, UC Davis; and R. Smith is Viticulture Farm Advisor, UC Cooperative Extension, Sonoma County. 